\title{
A STUDY ON WEAR BEHAVIOR OF Aa6061-Zrb 2 COMPOSITES BY USING PIN ON DISC
}

\author{
Pratik P. Patil \\ Department of Mechanical Design Engineering, \\ RIT, Islampur, Maharashtra, India
}

\author{
Dr. Ramchandra G. Desavale \\ Department of Mechanical Design Engineering, \\ RIT, Islampur, Maharashtra, India
}

\author{
Prof. Ganesh L. Suryawanshi \\ Department of Mechanical Design Engineering, \\ RIT, Islampur, Maharashtra, India
}

\begin{abstract}
Aluminum alloy AA6061 reinforced with $\mathrm{ZrB}_{2}$ particles by stir casting technique. $\mathrm{ZrB2}$ was manufactured by using from K2ZrF6 and KBF4 salts. The reinforcement percentage of $\mathrm{ZrB}_{2}$ is taken at $9 \%, 11 \%$, and $13 \%$. The AA6061-ZrB2 composite was manufactured for different stirrer speeds and different furnace temperature. The coefficient of friction of manufactured composite is determined by using Pin on Disc Setup in

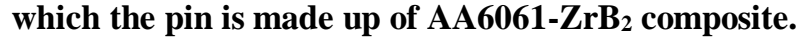

Keywords- Pin on Disc, Stir Casting, Coefficient of Friction.

\section{INTRODUCTION}

When metals are reinforced with ceramic particles it gives better properties than conventional alloys. Reinforcement material enhances the properties of matrix material such as strength and coefficient of friction with low wear resistance and lightweight. Aluminium Metal Matrix Composites (AMMC) are widely used in the aerospace and automobile industries. AMMC can be manufactured by different methods but in-situ stir casting is the most cost-effective among them.

"Baskaran et. al. (2015) [1] have presented dry sliding friction behavior of TIC reinforced AA7075 in-situ composites. They produced this metal matrix composite by stir casting by using AA7075 alloy, $\mathrm{K}_{2} \mathrm{TiF}_{6}$ halide salt, and graphite powders as raw materials."

"Kumar et. al. (2015) [2] have studied in situ reaction technique to produce AA5052 reinforced with $\mathrm{ZrB} 2$ particles and studied the mechanical properties of the composite. They produce AA5052-ZrB2 composites with different volume percent i.e. $0,3,6,9$, and $10 \% \mathrm{ZrB} 2$ particles were developed by in-situ reaction of molten AA5052 alloy with two inorganic salts $\mathrm{K} 2 \mathrm{ZrF} 6$ and $\mathrm{KBF} 4$ at a temperature of $860^{\circ} \mathrm{C}$."

"Ramesh et. al. (2011) [3] have studied the friction and wear behavior of Al 6063-TiB2 in-situ composite. Vicker's microhardness tester is used for hardness tests by applying a load of $100 \mathrm{~g}$ on a specimen for 10 seconds. Pin on disc apparatus is used to perform dry sliding and wear tests."

"Fakruddinali et. al. (2015) [4] were studied the wear behavior of Al6063-SiC-Gr hybrid composites. This hybrid composite was manufactured by a liquid metallurgy route. They studied the microstructure of composite by using Optical Emission Spectrometer. The wear test of both the matrix alloy and the developed hybrid composites were studied on the standard pin on disc wear test rig using wear-test samples for different loads."

"Kchaou et. al. (2013) [5] have presented different brake friction material characteristics under different loading conditions. Three different tests were conducted by using a pin on the disc setup. They studied the friction behavior of commercial brake pad with brass fiber.

"Suresh et. al. (2017) [6]. have presented wear depth and contact pressure study of Aluminium metal matrix composite in Pin on disk. Tribological properties of composites were studies and analyzed."

\section{MANUFACTURING OF COMPOSITE}

The AA6061-ZrB2 composite was manufactured by the stir casting technique.

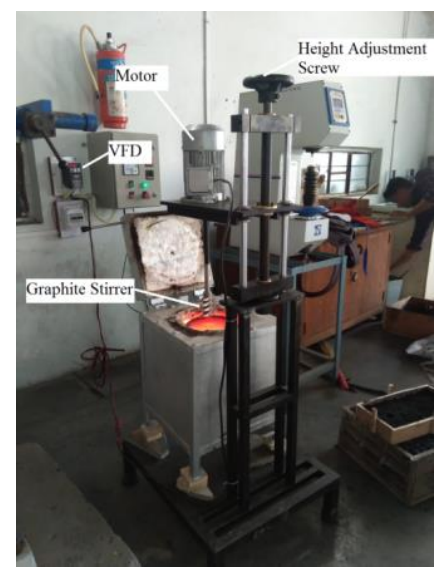




\section{International Journal of Engineering Applied Sciences and Technology, 2020 \\ Vol. 5, Issue 5, ISSN No. 2455-2143, Pages 91-94 \\ Published Online September 2020 in IJEAST (http://www.ijeast.com)}

Fig, 1. Stir Casting Furnace

AA6061 has reinforced with Zirconium Diboride with 9\%, $11 \%$, and $13 \%$ for different furnace temperatures $8250 \mathrm{C}$, $8500 \mathrm{C}$, and $8750 \mathrm{C}$ with varying stirrer speed 150,300 , and 450 RPM. By using Taguchi L9 Array in Minitab software following data can be estimated.

Table 1 Experimental Factors

\begin{tabular}{|c|c|c|}
\hline $\begin{array}{c}\mathrm{ZrB}_{2} \\
\%\end{array}$ & $\begin{array}{c}\text { Stirrer Speed } \\
(\mathrm{RPM})\end{array}$ & $\begin{array}{c}\text { Temperature } \\
\left({ }^{0} \mathrm{C}\right)\end{array}$ \\
\hline 9 & 150 & 825 \\
\hline 9 & 300 & 875 \\
\hline 9 & 450 & 825 \\
\hline 11 & 150 & 850 \\
\hline 11 & 300 & 825 \\
\hline 11 & 150 & 850 \\
\hline 13 & 300 & 875 \\
\hline 13 & 450 & \\
\hline
\end{tabular}

In the stir casting technique $\mathrm{KBF}_{4}$ and $\mathrm{K}_{2} \mathrm{ZrF}_{6}$ used in the ratio 52:48 to get the required percentage of Zirconium Diboride. The amount of salt poured in the crucible is given in table 1.

After melting of AA6061, $\mathrm{KBF}_{4}$ and $\mathrm{K}_{2} \mathrm{ZrF}_{6}$ salts are poured into the crucible. Then stirrer is immersed into the crucible and its speed is regulated by using variable frequency drive(VFD). VFD has a $1440 \mathrm{rpm}$ speed at $50 \mathrm{~Hz}$ frequency. Samples were made for three different stirrer speeds i.e. 150, 300, and 450 RPM. The stirring continues for 10 minutes.

Table 2 Material Weight

\begin{tabular}{|c|c|c|c|c|}
\hline $\begin{array}{c}\text { Reinfor } \\
\text { cement }\end{array}$ & $\begin{array}{c}\mathrm{AA6061} \\
(\mathrm{g})\end{array}$ & $\begin{array}{c}\mathrm{ZrB}_{2} \\
(\mathrm{~g})\end{array}$ & $\begin{array}{c}\mathrm{KBF}_{4} \\
(\mathrm{~g})\end{array}$ & $\begin{array}{c}\mathrm{K}_{2} \mathrm{ZrF}_{6} \\
(\mathrm{~g})\end{array}$ \\
\hline $9 \%$ & 500 & 45 & 117 & 108 \\
\hline $11 \%$ & 500 & 55 & 143 & 132 \\
\hline $13 \%$ & 500 & 65 & 169 & 156 \\
\hline
\end{tabular}

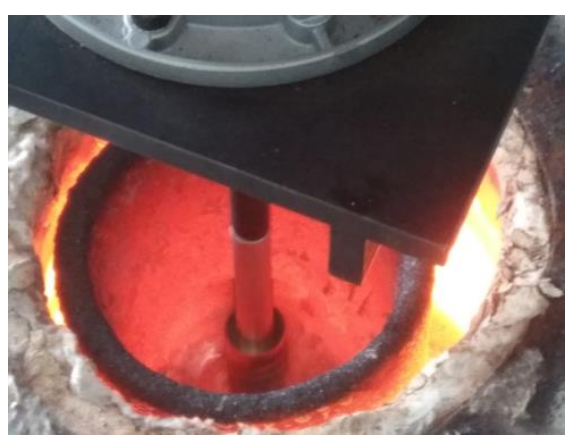

Fig.2. Stirring Mechanism

The hardness test was carried out by using the Brinell hardness tester. Brinell Test methods are carried out in the standards ASTM E10 and ISO 6506 standards.

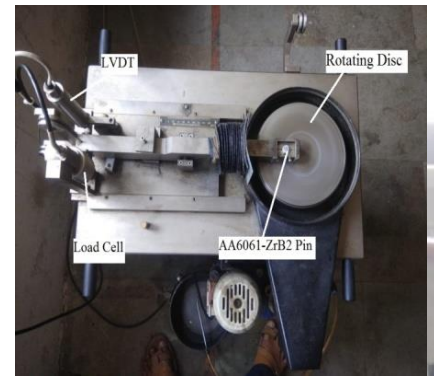

(a)

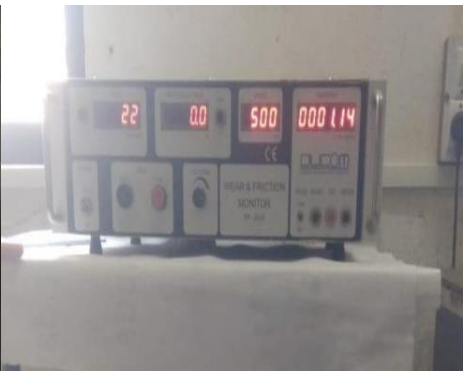

(b)
Fig.3. (a)DUCOM Pin on Disk Setup (b) Control Unit

The wear test of AA6061-ZrB2 composite was performed by using DUCOM Pin on the disc machine. The cylindrical pin is made up of composite material having a $12 \mathrm{~mm}$ diameter and $30 \mathrm{~mm}$ height while a disc made of EN8 material was used. The results were analyzed by using WINDUCOM 2010 software.

\section{RESULTS}

The Brinnel hardness test was carried out under $500 \mathrm{Kgf}$ for 30 seconds of dwell. The diameter of the diamond indenter used is $10 \mathrm{~mm}$ and the results were plotted by using MINITAB Software

Table 3 Brinnel Hardness Results

\begin{tabular}{|c|c|c|}
\hline $\begin{array}{c}\mathrm{ZrB} 2 \\
\%\end{array}$ & $\begin{array}{c}\text { The diameter of } \\
\text { Indentation } \mathrm{d}(\mathrm{mm})\end{array}$ & BHN \\
\hline 0 & 3.82 & 41.87 \\
\hline 9 & 3.30 & 56.85 \\
\hline 11 & 3.15 & 62.42 \\
\hline 13 & 2.98 & 70.72 \\
\hline
\end{tabular}




\section{International Journal of Engineering Applied Sciences and Technology, 2020 \\ Vol. 5, Issue 5, ISSN No. 2455-2143, Pages 91-94 \\ Published Online September 2020 in IJEAST (http://www.ijeast.com)}

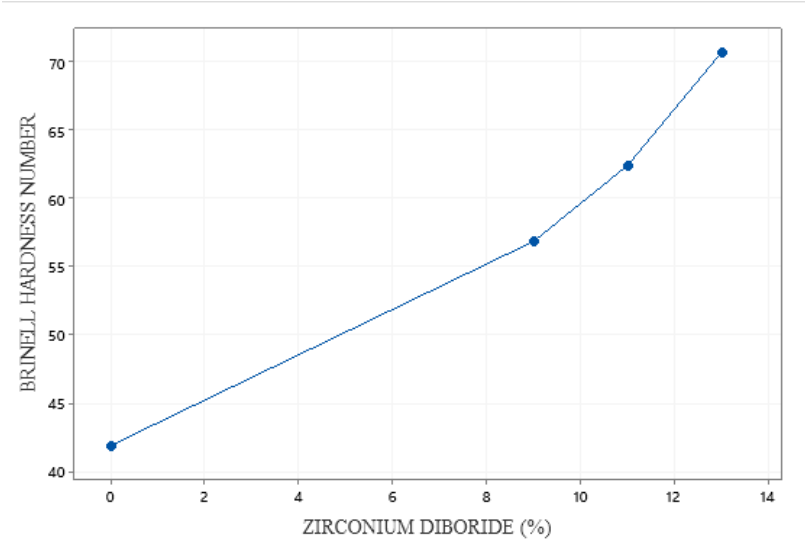

Fig.4. ZrB2 \% Vs BHN

The wear test is performed by using DUCOM Pin on Disc Tribometer (TR 20L). The disc is rotated at $500 \mathrm{rpm}$ and $2 \mathrm{Kg}$ load is applied to the pin. The experiment was carried out for 10 minutes.

Table 4 Wear Test Results

\begin{tabular}{|c|c|}
\hline ZrB2 \% & COF \\
\hline 0 & 0.43 \\
\hline 9 & 0.57 \\
\hline 11 & 0.58 \\
\hline 13 & 0.61 \\
\hline
\end{tabular}

When we plotted COF vs $\mathrm{ZrB} 2$ percentage, we get the following graph.

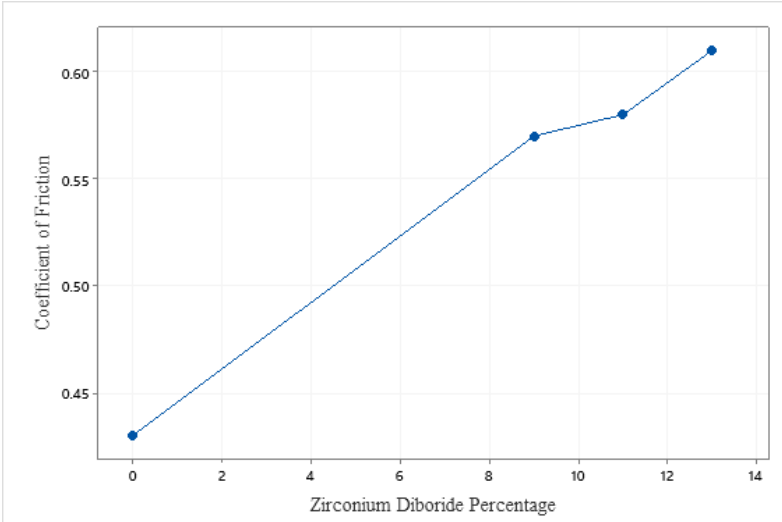

Fig $5 \mathrm{ZrB} 2 \% \mathrm{Vs}$ COF

\section{CONCLUSION}

It is observed that manufactured material is more uniform at higher stirrer speed i.e. $450 \mathrm{rpm}$ and high temperature i.e. 8750C. At these conditions, it is observed that there is less formation of slag as compared to lower stirrer speed and lower furnace temperature.

It is observed that the diameter of the indenter is reduced with an increase in the percentage of Zirconium Diboride. So it can be concluded from Brinell Hardness Test that hardness increases with an increase in reinforcement percentage.

Also from the wear test, it is observed that the coefficient of friction also increases with an increase in the percentage of Zirconium Diboride.

\section{REFERENCE}

[1] Baskaran, S., Anandakrishnan, V., Duraiselvam, D., and Keerthivasan, N., 2015 “A Study On Dry Sliding Friction Behaviour Of Tic Reinforced Aa7075 In-Situ Composites By Taguchi Analysis", International Journal of Mechanical And Production Engineering, ISSN: 23202092.

[2] Kumar, N., Gautam, R., and Mohan, S., 2015, "In-situ development of $\mathrm{ZrB} 2$ particles and their effect on microstructure and mechanical properties of AA5052 metal-matrix composites", Materials and Design, (pp. 129-136).

[3] Ramesh, C., and Ahamed, A., 2011, "Friction and wear behavior of cast Al 6063 based in situ metal matrix composites". Wear 271, (pp. 1928-1939).

[4] Fakruddinali, J., Noor, A., Badarinarayan, K., and Ahamed, A., 2015 "Wear Behaviour of Al 6061-SiC-Gr Hybrid Composites", ISSN(Online):2319-8753, Vol. 4, Issue 9.

[5] Kchaou, M., Sellami, A., and Elleuch, R., 2013 "Friction characteristics of a brake friction material under different braking conditions", Materials and Design.

[6] Suresh R., Kumar M. and Kiran T., 2017 “ Numerical stimulation and Experimental study of wear depth and contact pressure distribution of Aluminium MMC Pin on disc Tribometer." Materials Today: Proceedings 4, (pp. 11218-11228).

[7] 5) Çam, S., Demir, V., and Ozyurek, D., 2016 "Wear Behaviour of A356/TiAl3 in Situ Composites Produced by Mechanical Alloying", Metals.

[8] Kumar, N., Gautam, R., and Mohan, S., 2016 "Wear, friction and profilometer studies of in situ AA5052/ZrB2 composites", Tribology International 97, (pp. 313-326).

[9] 6) Kumar, S., and Balasubramanian, 1999, V., "Developing a mathematical model to evaluate wear rate of AA7075/SiCp powder metallurgy", Wear, pp. 10261034 
International Journal of Engineering Applied Sciences and Technology, 2020

Vol. 5, Issue 5, ISSN No. 2455-2143, Pages 91-94

Published Online September 2020 in IJEAST (http://www.ijeast.com)

[10] Ramesh, C., Ahamed, A., Channabasappa, B., Keshavamurthy, R., 2010 "Development of Al 6063-

TiB2 in situ composites", Materials \& Design, Volume 31, Issue 4, (pp. 2230-2236). 